\title{
A Case of Inverted Papilloma Originating from the Middle Ear
}

\author{
Jinsei Jung ${ }^{1}$, Younghoon $\mathrm{Kim}^{2}$ and Myung-Hyun Chung ${ }^{1}$ \\ ${ }^{l}$ Department of Otolaryngology, College of Medicine, Yonsei University, Seoul; and \\ ${ }^{2}$ National Health Insurance Corporation Ilsan Hospital, Goyang, Korea
}

\section{중이내에 발병한 반전성 유두종 1 예}

정진세 ${ }^{1} \cdot$ 김영훈 $^{2} \cdot$ 정명현 $^{1}$

연세대학교 의과대학 이비인후과학교실, ${ }^{1}$ 국민건강보험공단 일산병원 ${ }^{2}$

\author{
Received May 14, 2009 \\ Revised August 3,2009 \\ Accepted August 13, 2009 \\ Address for correspondence \\ Myung-Hyun Chung, MD, PhD \\ Department of Otolaryngology, \\ College of Medicine, \\ Yonsei University, \\ 260 Seongsan-ro, Seodaemun-gu, \\ Seoul 120-752, Korea \\ Tel $+82-2-2228-3609$ \\ Fax +82-2-393-0580 \\ E-mail mhchung@yuhs.ac
}

Inverted papilloma (Schneiderian-type papilloma) involving the middle ear is extremely rare. Most of cases originate from the mucosa of the lateral nasal wall, extending into the paranasal sinuses and orbits. Inverted papilloma involving the middle ear has a high recurrence rate and a possibility of malignant change. We experienced a case of inverted papilloma of the middle ear secondary to congenital cholesteatoma surgery. A nine-year old male who was diagnosed with congenital cholesteatoma was treated with intact canal wall tympanomastoidectomy. Nine months later, he underwent a second look operation. In the second surgery, a $3 \mathrm{~mm}$ round pinkish mass which was located at the tympanic orifice of Eustachian tube was identified as inverted papilloma. There was no recurrence of cholesteatoma or inverted papilloma four months after the $2^{\text {nd }}$ operation. Korean J Otorhinolaryngol-Head Neck Surg 2009;52:781-3

Key Words Inverted papilloma $\cdot$ Middle ear $\cdot$ Cholesteatoma.

\section{서 론}

반전성 유두종(inverted papilloma)은 비부비동의 외배 엽성 상피세포에서 기원하는 양성 종양이다. 비부비동에 발 생하는 종양 중 0.5 4\%를 차지하는 비교적 드문 종양으로 양성 종양이지만 국소적으로 침습적인 종양이다. ${ }^{1)}$ 반전성 유두종이 비인두, 눈물샘, 측두골을 침범한 경우가 보고된 적이 있으나 측두골에 원발성으로 생긴 반전성 유두종은 극 히 드문 경우로 전세계적으로 18 예가 보고되었으며 우리 나라에서는 아직까지 보고된 바 없다. ${ }^{2)}$ 저자들은 선천성 중 이염 수술 후 원발성으로 생긴 반전성 유두종을 1예 치험하 였기에 문헌고찰과 함께 보고하는 바이다.

\section{증 례}

9세 남자 환아로 수년 전부터의 우측 청력 감퇴를 주소 로 본원 내원하였다. 특이 내과적 과거력이 없는 환자로 문진
소견상 우측 청력 감소 이외에 이통, 이루, 어지럼증, 이명 등의 다른 특이 증상은 없었으며, 이학적 검사상 우측 고막 의 후상방에 하얀색 종물의 그림자가 보였으며, 중이내 선 천성 진주종이 의심되었다. 수술 전 순음 검사상 우측에 40 $\mathrm{dB}$ 의 전도성 난청이 있었으며 좌측은 정상이었고 임피던 스 검사상 양측 모두 $\mathrm{A}$ 형으로 정상이었다. 수술 전 측두골컴 퓨터촬영 (temporal bone computed tomographic scans) 에서 유양동의 함기화는 잘 되어 있으며, 우측 중이 내 추골 의 내, 외측으로 불규칙한 모양의 엽을 형성하는 연조직 음 영이 관찰되었고 등골과 침골의 연결상태는 연조직 음영으 로 불확실하였다(Fig. 1). 상고실 및 유돌동구는 정상이었 고 상고실 주변의 골미란 소견은 보이지 않았다. 중이강 내 의 연조직은 외이도 및 내이와의 연결은 없었으며 중이 내 에 국한된 조직이었다. 이관 및 하고실오목은 특이 소견 없 었으며 중이내 연조직과 직접적인 연결은 없었다(Fig. 2). 또한 양측 상악동 내 점막의 폴립모양의 비후를 보이고 있 으나 우측의 경우 경미한 정도였으며 육안 및 내시경 소견 
상 비강 및 비인두강은 정상 소견이었고 중이강 내의 병변 과의 직접적인 연결은 보이지 않았다. 선천성 진주종 의심 하에 외이도 후벽보존 유양돌기 절제술(intact canal wall tympanomastoidectomy)을 시행하였고, 중이강 내에 국한된 진주종으로 의심되는 흰색의 종물을 일괴로 제거하였다. 등 골의 상위구조는 종물에 의한 미란이 관찰되었고, 침골은 수 술 중 제거하였다. 조직검사 결과 진주종이 보고되었다(Fig. $3)$. 외래 추적 관찰 중 1 차 수술 후 8 개월에 시행한 순음검 사상 우측에 $60 \mathrm{~dB}$ 정도의 전도성 난청을 보였고, 고막의 후방부에 $2 \mathrm{~mm}$ 정도의 천공이 관찰되어 청력 증진 및 이차 추시수술(second look opertion)을 위하여 1차 수술 후 9 개월에 고실성형술 및 이소골성형술을 시행하였다. 경외이
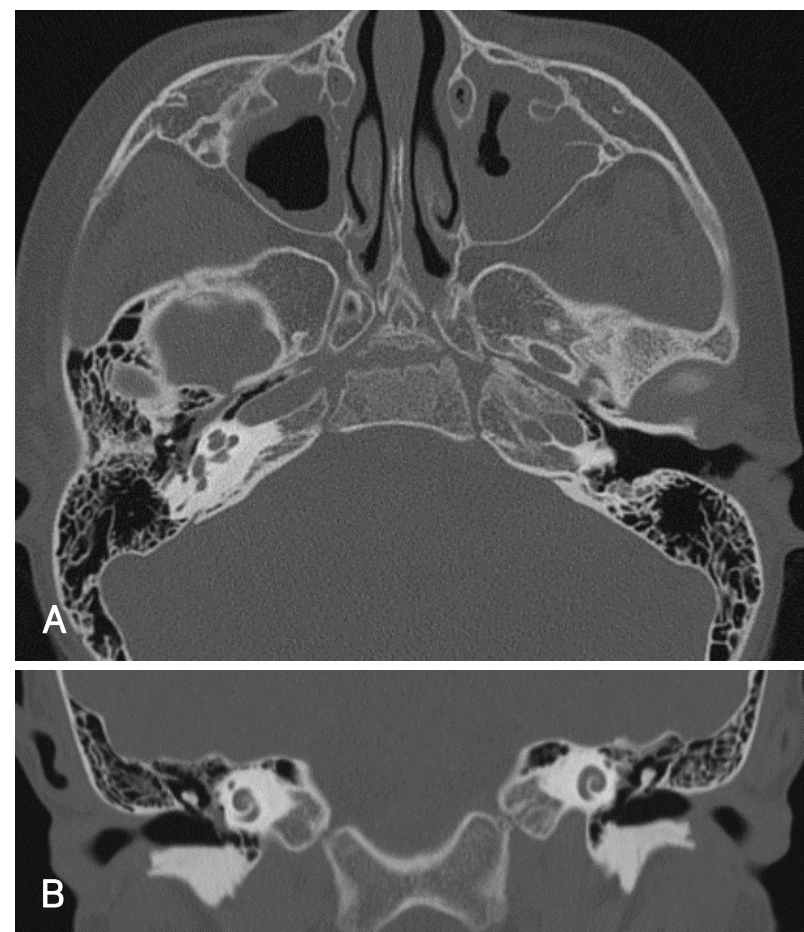

Fig. 1. Temporal bone computed tomographic scans (before the 1st operation) axial (A) and coronal (B) views. Soft tissue is present in middle ear cavity on the right side. It is polypoid and surrounds ossicular chain. Attic area is intact and mastoid air cells are well-pneumatized.
도 수술법으로 고실외이도피판을 절개하고 피부피판을 내 측으로 박리하여 고실개방을 한 후 70 도 $2.7 \mathrm{~mm}$ 내시경 을 이용하여 안신경와 및 고실 굴을 포함해 고실 전체를 확 인한 결과 진주종의 재발 소견은 관찰되지 않았다. 하지만 골부 이관 입구부에 삼출액으로 덮인 $3 \mathrm{~mm}$ 크기의 폴립모 양 연조직이 독립적으로 있어 제거 후 조직검사를 시행하 였다. 중이강 내에 다른 특이 문제는 없었으며, 폴리에틸렌 (polyethylene) 재질의 total ossicular replacement prosthesis (TORP)를 이용하여 이소골 성형술을 시행하였고, 이개 연골의 연골막을 이용하여 고막성형술을 시행 후 수술 을 종료하였다. 조직검사 결과는 반전성 유두종(Schneide-
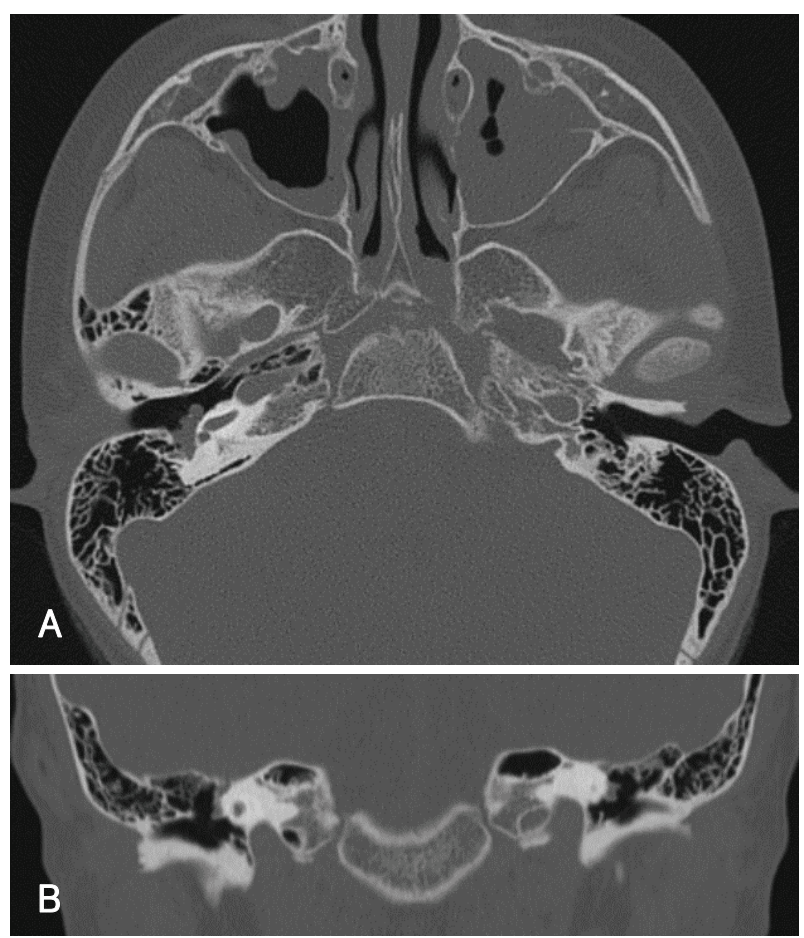

Fig. 2. The Eustachian tube and hypotympanic-jugular recess in preoperative temporal bone CT scans (before the 1st operation) are clear on axial view (A) and coronal view (B). Polypoid soft tissue is not connected directly to the Eustachian tube orifice. Right maxillary sinus mucosa was polypoid and thick, but the mucosa of nasal cavity and nasopharynx was normal and no abnormal finding is in the nasal endoscopy.
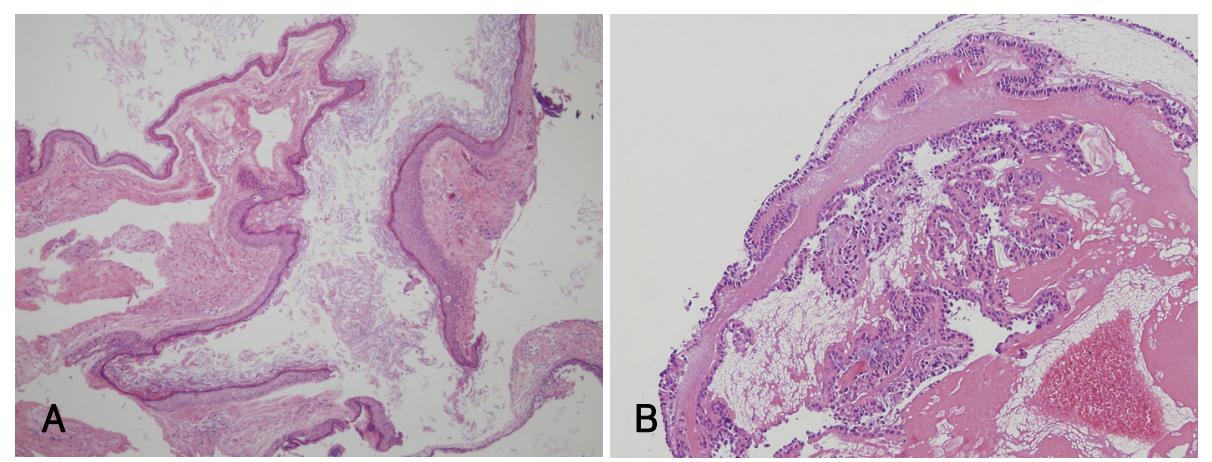

Fig. 3. Histological findings. Cholesteatoma (the 1st operation specimen) is lined by keratinizing squamous epithelium and keratin debris is shown $(H \& E$ stain, $\times 40)(A)$. Inverted papilloma (the 2 nd operation specimen) shows endophytic or inverted growth pattern as finger-like projection $(\mathrm{H} \& \mathrm{E}$ stain, $\times 100)(B)$ 
rian papilloma)이 나왔으며 2차 수술 후 2개월째 시행한 순음검사상 우측에 $30 \mathrm{~dB}$ 의 전도성 난청이 있었으나 수술 전에 비하여 청력개선의 효과가 있었다. 이후 추가 치료 없 이 4 개월째 외래 추적 관찰 중으로 재발 소견은 보이지 않 았다.

\section{고 찰}

중이를 침범한 반전성 유두종은 매우 드물다. 1987년 Stone 등 ${ }^{3)}$ 에 의해 처음으로 측두골을 침범한 반전성 유두종 이 발표된 이래 전 세계적으로 18 예만이 보고되었다. 따라 서 이 질병에 대해 자세히 알려진 바는 없지만 원인으로서 이관을 따라 직접적인 전파, 다발적인 발생, 비부비동을 형 성하는 외배엽성 Schneiderian 막의 비부비동 외 전이 등 이 거론되고 있다. ${ }^{4-6)}$ 또한 만성 염증으로 인한 중이 점막 의 화생에 의해 반전성 유두종이 유발된다는 주장도 있다. ${ }^{2)}$

본 예는 선천성 진주종이 생겼던 중이 점막에서 원발성으 로 반전성 유두종이 생긴 경우로 지금까지 보고되었던 측 두골에 생긴 반전성 유두종에서는 볼 수 없었던 경우이다. 첫 수술에서 중이강 내에 국한된 진주종을 제거한 후 이차 수술에서 진주종의 재발없이 골성 이관의 입구(중이갑각 앞 부분)에서 반전성 유두종이 발견되었다. 첫 수술 전 영상 학적 검사에서 이관입구부에 유두종괴를 의심할 만한 소견 은 보이지 않았으며, 진주종 수술 당시에도 이관입구부에 확 연한 종괴의 모습은 관찰되지 않았기 때문에 반전성 유두종 의 발생은 일차 수술 이후로 추측된다. 부비동 점막의 비후 및 부종이 동반되었으나 코의 신체검진상 비강 및 비인강 의 점막은 정상이었으며, 이외에 구강, 구인두, 하인두 및 후두에 어디에서도 유두종을 발견할 수 없었다. 양측 이관 의 비인두 기시부 주변에 이상 소견이 없던 것으로 보아 비 부비동과 상관없이 중이나 이관 기원의 원발성 중이 내 반전 성 유두종으로 추측된다.

중이강 내에 생긴 반전성 유두종과 인간 유두종 바이러스 (human papilloma virus, HPV) 와의 연관성은 확실치 않 다. 비부비동에 생긴 반전성 유두종의 경우 HPV 감염이 발 견될 확률은 11 61\%로 다양하게 보고되었지만 중이강 및 유양동에 생긴 반전성 유두종에서는 $\mathrm{HPV}$ 감염이 보고된 바 없다. ${ }^{78)}$ 본 예에서 조직의 in situ hybridization 또는 polymerase chain reaction(PCR) assay를 시행하면 진단에 도움이 될 것으로 생각되나 시행하지는 않았다. 또한 비부 비동에 생긴 반전성 유두종은 $\mathrm{HPV} 11,18$ 감염과 관련하 여 악성화 가능성이 약 $9 \%$ 정도로 알려져 있고, 현재까지 보고된 중이강 내에 생긴 반전성 유두종에서 편평 상피 세포
암이 발견된 경우는 $33 \%$ 정도이며 이 모든 경우에서 비부 비동과 중이강 양측에서 반전성 유두종이 발견되었다. ${ }^{9,10)}$ 하 지만 비부비동을 침범하지 않은 중이 내 반전성 유두종이 더라도 악성화 가능성을 완전히 배제할 수 없으므로 엄격 한 외래 추적 및 관찰이 필요하다. 기존의 예들에서 측두골 내 반전성 유두종이 발병한 평균 나이가 46.5세임을 고려 해볼 때 본 예에서는 10 세 미만의 어린 나이인 환자여서 반전성 유두종 가능성을 수술 전에 미처 생각하지 못하였다. 첫 수술에 의해 발생한 육아종성 조직으로 생각하고 광범위 한 절제는 하지 않았으나 잔존하는 이상조직은 없다고 판단 하여 이차 수술 후 추가 치료는 하지 않았으며 정기적인 외 래 추적 관찰만 계획하고 있다. 하지만 비부비동에 생긴 반 전성 유두종의 재발률이 매우 높고, 기존에 발표되었던 중이 내 반전성 유두종 18예 중 50\%에서 국소 재발하였기 때문 에 환자 및 보호자에게 재발 가능성 및 재수술 가능성을 충 분히 설명하였다. 또한 악성화의 가능성을 설명하였고 이럴 경우 광범위한 측두골 수술이 필요하다는 것을 주지시켰다.

본 증례는 선천성 진주종 수술 이후 생긴 중이 내 반전성 유두종으로서 국내에서 처음 보고한 예이다. 중이 내에 생 긴 반전성 유두종은 매우 드문 질환으로 아직까지 임상적 특성들이 잘 알려져 있지 않았지만 높은 재발률 및 악성화 가능성으로 철저한 외래 추적 및 관찰이 필요하다.

\section{REFERENCES}

1) Kaufman MR, Brandwein MS, Lawson W. Sinonasal papillomas: clinicopathologic review of 40 patients with inverted and oncoytic Schneiderian papillomas. Laryngoscope 2002;112 (8 Pt 1):1372-7.

2) de Filippis C, Marioni G, Tregnaghi A, Marino F, Gaio E, Staffieri A Primary inverted papilloma of the middle ear and mastoid. Otol Neurotol 2002;23 (4) :555-9.

3) Stone DM, Berktold RE, Ranganathan C, Weitr RJ. Inverted papilloma of the middle ear and mastoid. Otolaryngol Head Neck Surg $1987 ; 97(4): 416-8$.

4) Kaddour HS, Woodhead CJ. Transitional papiloma of the middle ear. J Laryngol Otol 1992;106 (7) :628-9.

5) Wenig BM. Schneiderian-type mucosal papillomas of the middle ear and mastoid. Ann Otol Rhinol Laryngol 1996;105 (3) :226-33.

6) Seshul MJ, Eby TL, Crowe DR, Peters GE. Nasal inverted papilloma with involvement of middle ear and mastoid. Arch Otolaryngol Head Neck Surg 1995;121 (9):1045-8.

7) Kraft M, Simen D, Casas R, Pfaltz M. Significance of human papillomavirus in sinonasal papillomas. J Laryngol Otol 2001;115(9): 709-14.

8) Saegusa M, Mitta H, Hashimura M, Okayasu I. Downregulation of p27 expression is correlated with increased cell proliferation but not expression of $\mathrm{p} 21$ and $\mathrm{p} 53 \mathrm{~m}$, and human papillomavirus infection in benign and malignant tumours of sinonasal regions. Histopathology 1999;35 (1) :55-64.

9) Lawson W, Ho BT, Shaari Cm, Biller HF. Inverted papilloma: a report of 112 cases. Laryngoscope 1995;105 (3 Pt 1) :282-8.

10) Elena Gaio, Gino Marioni, Stella Blandamura, Alberto Staffieri. Inverted papilloma involving the temporal bone and its association with squamous cell carcinoma: critical analysis of the literature. Expert Rev Anticancer Ther 2005;5 (2):391-7. 